Check for updates

Cite this: RSC Adv., 2017, 7, 25475

\title{
Biofilms formed within the acidic and the neutral biotrickling filters for treating $\mathrm{H}_{2} \mathrm{~S}$-containing waste gases
}

\author{
Xiang Tu, ${ }^{\text {ab Jun Guo, }}{ }^{\text {ab }}$ Yonggang Yang, ${ }^{b}$ Rongfang Feng, ${ }^{\text {ab }}$ Guoping Sun ${ }^{b}$ \\ and Jianjun Li $\mathbb{D}$ *b
}

Biofiltration of waste gases relies heavily on the biofilm on the surface of packing materials, whose formation has been believed to be associated with various environmental factors. In this study, we characterized two types of biofilms that are developed within an acidic and a neutral biotrickling filter (BTF), respectively. Both BTFs obtained near $100 \%$ removal efficiency when the $\mathrm{H}_{2} \mathrm{~S}$ inlet loading rate was lower than $12.5 \mathrm{~g} \mathrm{~m}^{-3} \mathrm{~h}^{-1}$. As the rate was increased to $25 \mathrm{~g} \mathrm{~m}^{-3} \mathrm{~h}^{-1}$, however, the performance of the neutral BTF seemed to be compromised, with a decrease of $12.2 \%$ in removal efficiency, compared with a slight drop of $0.4 \%$ in the acidic one. The biomass in the neutral BTF ranged from 2.13 to 5.76 mgvss $g_{\text {packing }}{ }^{-1}$, which was higher than that seen in the acidic BTF (from 1.22 to 4.64 mgvss $_{\text {packing }}{ }^{-1}$ ). Based on what was observed, we inferred that the stability of biofilms was influenced by the inlet loading rate and $\mathrm{pH}$ fluctuations. Besides, the ratio of planktonic cells : biofilm for the acidic BTF were higher than those of the neutral BTF, and polysaccharide was the dominant component of EPS. The maximum amounts of polysaccharide were $28.4 \mathrm{mg} \mathrm{gvss}^{-1}$ for the neutral BTF and $156.2 \mathrm{mg} \mathrm{gvss}^{-1}$ for the acidic one, while the corresponding protein amounts were only 11.2 and $5.4 \mathrm{mg} \mathrm{gvss}^{-1}$, indicating that the polysaccharide in the EPS may play an important role in maintaining the mechanical stability of biofilm in extremely acidic conditions. Finally, we sampled some biofilms from the BTFs, whose three-dimensional structures were visualized by a confocal laser scanning microscopy (CLSM), and showed that the innermost layer of all biofilms exhibited the highest bacterial viabilities.

Received 10th April 2017

Accepted 5th May 2017

DOI: $10.1039 / c 7 r a 04053 a$

rsc.li/rsc-advances degraded into simple compounds., ${ }^{2,13,14}$ Although previous reports have evaluated the influences of packing materials, $\mathrm{pH}$, inlet loading rates and dissolved oxygen on the removal performance of bioreactor, the detailed mechanism concerning the formation of biofilms in acidic BTF as well as their associations with various environmental parameters and microbial species remain largely unclear. ${ }^{15-17}$ Inside the biofilms, microbial cells are kept together by extracellular polymeric substances (EPS) in close proximity. ${ }^{18}$ EPS act as a protective barrier that can prevent cells from damages caused by various adverse factors..$^{19}$ The formation of the biofilm has been found to be related with the microbial species, surface properties and other various environmental factors. ${ }^{20-22}$ However, only limited investigation has been done regarding biofilms formed in acidic conditions. ${ }^{23,24}$

The knowledges on how the biofilm forms in an extremely acidic BTF or what happened to the biofilm structure when $\mathrm{pH}$ is changed, are very important for designing the bioreactor configuration, and for optimizing the running parameters. Biofilm formation is a dynamic process that involves both the recruitment of planktonic cells to settle down and the release of attached cells back to planktonic forms. ${ }^{25}$ Previous studies had emphasized the characterization of mature biofilms, whose

\footnotetext{
${ }^{a}$ School of Bioscience and Bioengineering, South China University of Technology, Guangzhou, 510006, PR China

${ }^{b}$ Guangdong Institute of Microbiology, State Key Laboratory of Applied Microbiology Southern China, Guangdong Provincial Key Laboratory of Microbial Culture Collection and Application, Guangzhou, 510070, PR China. E-mail: lijianjun1672@ 163.com
} 
properties were largely determined by the attached microbial community, and failed to pay sufficient attention to the biomass of planktonic cells. ${ }^{26,27}$ However, in the BTF, packing bed are usually packed with porous materials such as volcanic stone. The surface of such filters is very rough, and has numerous pits on it. Thus, planktonic cells are not easily washed off due to the slow velocity of liquid fluid. These cells can be retained inside the packing bed, and take part in the biodegradation of pollutants in a similar manner to the tightly attached biofilm. ${ }^{28}$

In the present study, experiments were designed and carried out to evaluate effects of $\mathrm{pH}$ and inlet loading rates on the removal performance of the BTF under both $\mathrm{pH}$ neutral and acidic conditions. The ratios of planktonic cells to biofilm, and polysaccharide to protein were also determined to assess the effect of $\mathrm{pH}$ and inlet loading rate on the stability of biofilm. Finally, the three-dimensional structures of biofilms were directly visualized in situ using CLSM.

\section{Materials and methods}

\subsection{Biotrickling filters setup and operation}

The schematic of two biotrickling filters was showed in Fig. 1. Packing columns were made of plexiglass with an inner diameter of $8 \mathrm{~cm}$ and a total height of $60 \mathrm{~cm}$, and each column was composed of three separated compartments in a stacked configuration, named BTFa-u/m/b and BTFn-u/m/b. Each compartment had an effective volume of $1.0 \mathrm{~L}$. Volcanic stones, with particle sizes of $0.5-1.0 \mathrm{~cm}$, porosity of $70 \%$ and bulk density of $739 \mathrm{mg} \mathrm{cm}^{-3}$, were used as packing materials and were supported with a perforated sieve plate at the bottom of column. To analyse biofilms of packing bed, packing materials were collected at sites of 2, 20, 40 and $60 \mathrm{~cm}$ distant from the bottom of column, respectively. Three ports were set along the column for gas sampling. Synthetic waste gases were generated by mixing $\mathrm{H}_{2} \mathrm{~S}$ vapours with a fresh airstream in a mixing chamber. The nutrient solution containing $1 \mathrm{~g} \mathrm{~L}^{-1}$ of $\mathrm{NH}_{4} \mathrm{Cl}, 0.12 \mathrm{~g} \mathrm{~L}^{-1}$ of $\mathrm{KH}_{2} \mathrm{PO}_{4}$, $0.15 \mathrm{~g} \mathrm{~L}^{-1}$ of $\mathrm{K}_{2} \mathrm{HPO}_{4}, 0.02 \mathrm{~g} \mathrm{~L}^{-1} \mathrm{CaCl}_{2}, 0.2 \mathrm{~g} \mathrm{~L}^{-1} \mathrm{MgSO}_{4}$, and 1

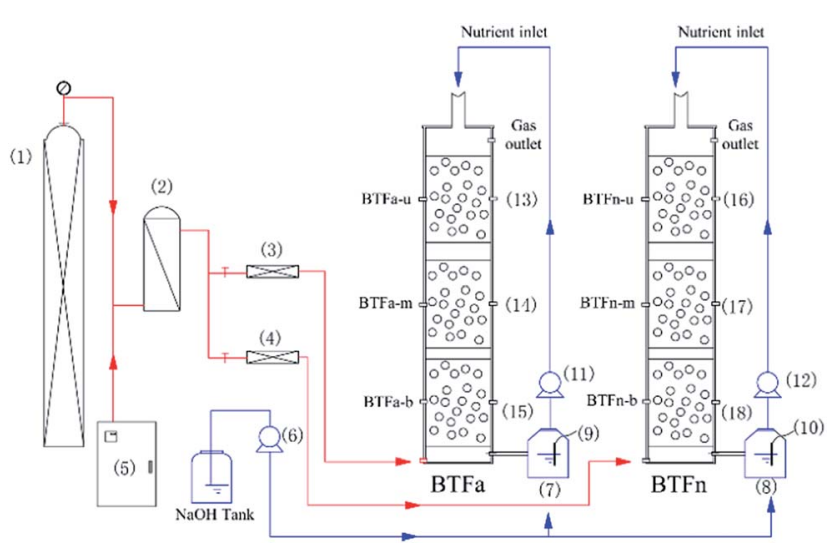

Fig. 1 Schematic diagram of the biotrickling filter (1) $\mathrm{H}_{2} \mathrm{~S}$ cylinder, (2) mixing chamber, (3 and 4) gas flowmeter, (5) air compressor, (6) $\mathrm{NaOH}$ dosing pump, (7 and 8 ) nutrient tank, (9 and 10) pH probe, (11 and 12) peristaltic pump, (13-15) filter material sampling sites, (16-18) air sampling ports.
$\mathrm{mL} \mathrm{L}^{-1}$ trace elements, was stored in a stirring flask, and was continuously pumped into the BTF using a peristaltic pump

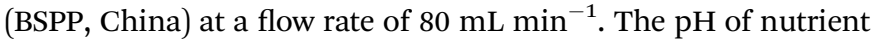
solution was adjusted to 4.0 for the acidic biotrickling filter (BTFa), and 7.0 for the neutral one (BTFn) using a dosing pump (SKEO, Italy), which had been automatically introducing $1 \mathrm{M}$ $\mathrm{NaOH}$ to the solution in real-time. Besides, the nutrient solution was refreshed periodically to ensure sufficient nutrient and moisture for the growth of microorganisms, as well as to avoid accumulation of metabolic product.

To develop microbial communities with a broad tolerance range of $\mathrm{pH}$, the inoculum for both BTFs was a combination of acclimated microbial consortium in labs and the activated sludge. Further details of the inoculation were described elsewhere. ${ }^{11}$ The experiment was divided into three stages marked by different $\mathrm{H}_{2} \mathrm{~S}$ inlet loading rates that once the two BTFs reached the steady state, the rate was stepwise increased from 7.5 to $12.5 \mathrm{~g} \mathrm{~m}^{-3} \mathrm{~h}^{-1}$ on day 13 , and then to $25 \mathrm{~g} \mathrm{~m}^{-3} \mathrm{~h}^{-1}$ on day 25 . The empty bet retention time was kept at $60 \mathrm{~s}$ throughout the experiment.

\subsection{Analysis of the biomass and the EPSs}

For determining biomass both in the form of biofilm and planktonic cells, packing materials were sampled in triplicate, and were treated according to the methods established by Harneit and Ramírez with some modifications. ${ }^{29,30}$ Briefly, $10 \mathrm{~g}$ packing materials were mixed with $20 \mathrm{~mL}$ sterile saline in a 50 $\mathrm{mL}$ centrifugal tube. After gently shaking, the suspension was collected for the quantification of planktonic biomass. The packing materials were then transferred to a new centrifuge tube and re-mixed with $20 \mathrm{~mL}$ sterile saline. Biofilms were detached from the surface of packing materials by ultrasonication for $3 \mathrm{~min}$, and the suspension was collected for the quantification of biofilm biomass. The two suspensions were centrifuged at $20000 \mathrm{rpm}$ for $30 \mathrm{~min}$. The resulting pellets were first kept at $105{ }^{\circ} \mathrm{C}$ in an oven for two hours to remove the remaining water, and were dried out at $550{ }^{\circ} \mathrm{C}$ for $4 \mathrm{~h}$. The weight difference of pellets before and after drying at $550{ }^{\circ} \mathrm{C}$ was measured, which was predominantly the mass of volatile suspended solid (VSS) and had represented the biomass.

EPS were extracted according to the method of Zhu et al. ${ }^{31}$ Packing materials of $10 \mathrm{~g}$ were mixed with $20 \mathrm{~mL}$ sterile saline, and were ultrasonicated at $40 \mathrm{kHz}$ for $50 \mathrm{~s}$ with an interval of $3 \mathrm{~s}$. After vortexing for $1 \mathrm{~min}$, the suspensions was collected and centrifuged for $20 \mathrm{~min}$ at $4{ }^{\circ} \mathrm{C}, 14000 \mathrm{~g}$, and were then flushed through a $0.22 \mu \mathrm{m}$ filter to ensure a complete removal of cells. Among these extracted cell-free EPS, polysaccharide was quantified colorimetrically by using glucose as the standard, and similarly bovine serum albumin was used as standard to quantify protein content by the method of Liu et al. ${ }^{32}$ All analyses were in triplicate in order to ensure reproducibility and representativeness. ${ }^{33}$

\subsection{Elemental sulfur extraction and analysis}

Elemental sulfur in biofilms was extracted and its content was determined using HPLC according to the method of Bobadilla 
et al. with some modifications. ${ }^{34-36}$ Briefly, $10( \pm 1)$ g packing materials were immersed within $10 \mathrm{~mL} 0.2 \mathrm{M} \mathrm{NaOH}$ in a $50 \mathrm{~mL}$ centrifuge tube, incubated at $100{ }^{\circ} \mathrm{C}$ for $10 \mathrm{~min}$, and were then ultrasonicated at $40 \mathrm{kHz}$ for $10 \mathrm{~min}$. Filter-material-free solution with biofilm inside was centrifuged at $12000 \mathrm{rpm}$ for $10 \mathrm{~min}$, whose supernatant was then discarded. The resulting pellet was mixed with $10 \mathrm{~mL}$ of $\mathrm{CS}_{2}$, and was again ultrasonicated for $10 \mathrm{~min}$. The mixture was filtered with $0.22 \mu \mathrm{m}$. The content of elemental sulfur was determined using HPLC with a $\mathrm{C} 18$ column at $254 \mathrm{~nm}$ of wavelength. The mobile phase consisted of $95 \% \mathrm{v} / \mathrm{v}$ methanol and the flow rate was set at 0.8 $\mathrm{mL} \min ^{-1}$.

\subsection{Confocal laser scanning microscopy (CLSM)}

A three-dimensional visualization seemed indispensable to fully determine/investigate the internal structure of biofilms inside the filter bed, which was achieved by the CLSM, facilitated with the pre-mixed carbon plates in each filter layer. The procedure was described elsewhere. ${ }^{37}$ Briefly, carbon plates were carefully taken from the packing bed using sterile tweezers, and were immediately immersed in the PBS solution. Subsequently, biofilm samples were stained with the LIVE/DEAD BacLight staining kit (Invitrogen) for 10 minutes, prior to the observation under CLSM (LSM 700, Zeiss). At least 10 random view-fields $(600 \times 600 \mu \mathrm{m}$ for each field $)$ were observed and analysed for each biofilm sample. There-dimensional structure was obtained using the "Stack" model of the Zen software (Zeiss). The biofilm viability was calculated based on the ratio of viable to total cells. $^{37}$

\subsection{In vitro sulfur oxidation ability of biofilm}

Flask experiments were conducted to profile the sulfur oxidation capability of planktonic cells and biofilm. The solution with biomass concentration of $1 \mathrm{mg}_{\mathrm{vss}} \mathrm{L}^{-1}$ was inoculated to 50 mL nutrient solution (10 $\mathrm{g} \mathrm{L}^{-1}$ elemental sulfur, $1 \mathrm{~g} \mathrm{~L}^{-1} \mathrm{NH}_{4} \mathrm{Cl}$, $0.12 \mathrm{~g} \mathrm{~L}^{-1} \mathrm{KH}_{2} \mathrm{PO}_{4}, 0.15 \mathrm{~g} \mathrm{~L}^{-1} \mathrm{~K}_{2} \mathrm{HP}_{4}, 0.02 \mathrm{~g} \mathrm{~L}^{-1} \mathrm{CaCl}_{2}, 0.2 \mathrm{~g} \mathrm{~L}^{-1}$ $\mathrm{MgSO}_{4}$, and $1 \mathrm{~mL} \mathrm{~L}{ }^{-1}$ trace elements). The solution with biomass concentration of $1 \mathrm{mg}_{\mathrm{vss}} \mathrm{L}^{-1}$ was inoculated to $50 \mathrm{~mL}$ nutrient solution (10 $\mathrm{g} \mathrm{L}^{-1}$ elemental sulfur, $1 \mathrm{~g} \mathrm{~L}^{-1} \mathrm{NH}_{4} \mathrm{Cl}$, $0.12 \mathrm{~g} \mathrm{~L}^{-1} \mathrm{KH}_{2} \mathrm{PO}_{4}, 0.15 \mathrm{~g} \mathrm{~L}^{-1} \mathrm{~K}_{2} \mathrm{HP}_{4}, 0.02 \mathrm{~g} \mathrm{~L}^{-1} \mathrm{CaCl}_{2}, 0.2 \mathrm{~g} \mathrm{~L}^{-1}$ $\mathrm{MgSO}_{4}$, and $1 \mathrm{~mL} \mathrm{~L}^{-1}$ trace elements). The $\mathrm{pH}$ of each nutrient solution was adjusted to what has been tested in situ. Thereafter, the culture flasks were incubated at $30{ }^{\circ} \mathrm{C}$, gentle rotated at $180 \mathrm{rpm}$ in the shaker. The nutrient solution was sampled once every two hour. ${ }^{38}$ Sulfate, sulfite and thiosulfate were determined using an ion chromatograph (Dionex ICS-1500, USA) with an AS19/AG19 column (Dionex, USA).

\subsection{Determination of sulfur in gas-phase}

Gas-phase concentration of $\mathrm{H}_{2} \mathrm{~S}$ in the biofilters was measured with a gas chromatograph (Shimadzu GC-2010, Japan) equipped with an FPD detector. The column used was GS-Gas Pro capillary column $(30 \mathrm{~m} \times 0.32 \mathrm{~mm} \times 1.0 \mu \mathrm{m}$, Agilent Technologies, USA). Gas samples were taken using Tedlar bags of 2 L. Total volume of $100 \mu \mathrm{L}$ was injected into the GC using a gastight syringe. The temperature settings of the injector and detector were fixed at $70{ }^{\circ} \mathrm{C}$ and $250{ }^{\circ} \mathrm{C}$, respectively. The oven was initially set at $80^{\circ} \mathrm{C}$ for $2 \mathrm{~min}$, with a $10{ }^{\circ} \mathrm{C}$ increase for every minute until it reached $250^{\circ} \mathrm{C}$, and was finally shut down after letting stand for $5 \mathrm{~min}$.

\section{Results and discussion}

\section{1 $\mathrm{H}_{2} \mathrm{~S}$ removal performance of the acidic BTF and the neutral BTF}

$\mathrm{H}_{2} \mathrm{~S}$ removal profiles of the two BTFs were showed in Fig. 2. Near $100 \%$ removal efficiencies (REs) were achieved by both BTFs at the inlet loading rates of 7.5 and $12.5 \mathrm{~g} \mathrm{~m}^{-3} \mathrm{~h}^{-1}$. However, once the inlet loading rate increased to $25 \mathrm{~g} \mathrm{~m}^{-3} \mathrm{~h}^{-1}$ on day 25 , the REs decreased by $0.4 \%$ in BTFa, and by $12.18 \%$ in BTFn, respectively. Both BTFs mainly relied on the bottom packing layer to remove $\mathrm{H}_{2} \mathrm{~S}$ in all case of inlet loading rates. This situation was especially true in BTFa, indicating the bottom packing bed in BTFa had higher removal capacity. López et al. reported a similar result in a one-stage biotrickling filter for the removal of a mixture of $\mathrm{H}_{2} \mathrm{~S}$, methanol and $\alpha$-pinene. ${ }^{39}$ Ramirez et al. also observed that most $\mathrm{H}_{2} \mathrm{~S}$ were removed by the bottom packing bed. ${ }^{40}$ Although the upper and the middle packing layers contributed minor $\mathrm{H}_{2} \mathrm{~S}$ removal, these sections were very helpful in alleviating the loading shocks that commonly occurs in practice.

Fig. 2 also showed a significant difference between of the two BTFs in terms of their tolerance to shock loads. The BTFa behaved much more robust when facing the strong fluctuation of inlet loading rates. For instance, on 25th day, the $\mathrm{H}_{2} \mathrm{~S}$ RE of the bottom packing layer slightly decreased from $99.31 \%$ to $87.89 \%$ in BTFa, while sharply decreased from $93.24 \%$ to $54.68 \%$ in BTFn. Our previous study showed that BTF tended to develop microbial communities mainly composed of Acidithiobacillus genera in acidic environment. Abundant acidophilic microbes greatly enhanced the $\mathrm{H}_{2} \mathrm{~S}$ removal capacity of the BTF in extremely acidic conditions. ${ }^{11}$

\subsection{Comparison of biomass and composition of biofilm between the two BTFs}

Total biomasses in the different packing layer were summarized in Table 1. The ratios of planktonic biomass to biofilm biomass were also provided. The amount of biomass in BTFa ranged from 1.22 to $4.64 \mathrm{mg}_{\mathrm{vss}} \mathrm{g}_{\text {packing }}{ }^{-1}$. It seems that biomass correlated with the total amount of S source including $\mathrm{H}_{2} \mathrm{~S}$ and the elemental sulfur. The largest biomass was found being in the bottom packing layer, which was near to the inlet port.

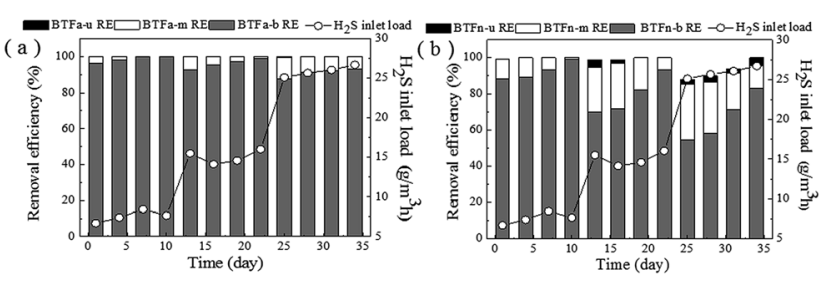

Fig. $2 \mathrm{H}_{2} \mathrm{~S}$ removal profiles of the BTFa (a) and the BTFn (b). 
Table 1 Spatial distribution of biomass, planktonic cells to biofilm and sulfur of packing samples

\begin{tabular}{|c|c|c|c|c|c|c|c|c|c|}
\hline \multirow[b]{2}{*}{ Sampling location } & \multirow{2}{*}{$\begin{array}{l}\text { Inlet load } \\
\left(\mathrm{g} \mathrm{m}^{-3} \mathrm{~h}^{-1}\right)\end{array}$} & \multicolumn{4}{|l|}{ BTFa } & \multicolumn{4}{|l|}{ BTFn } \\
\hline & & $2 \mathrm{~cm}$ & $20 \mathrm{~cm}$ & $40 \mathrm{~cm}$ & $60 \mathrm{~cm}$ & $2 \mathrm{~cm}$ & $20 \mathrm{~cm}$ & $40 \mathrm{~cm}$ & $60 \mathrm{~cm}$ \\
\hline \multirow[t]{3}{*}{ VSS (mg vss $\left._{\text {packing }}{ }^{-1}\right)$} & 7.50 & 3.24 & 1.77 & 1.49 & 2.27 & 4.01 & 3.34 & 3.17 & 3.53 \\
\hline & 12.50 & 3.50 & 1.64 & 1.22 & 2.37 & 5.26 & 3.13 & 2.45 & 3.00 \\
\hline & 25.00 & 4.64 & 2.26 & 1.35 & 3.31 & 5.76 & 2.92 & 2.13 & 3.17 \\
\hline \multirow[t]{3}{*}{ Planktonic/biofilm(vss) } & 7.50 & 0.22 & 0.73 & 0.72 & 0.44 & 0.16 & 0.05 & 0.06 & 0.10 \\
\hline & 12.50 & 0.87 & 0.86 & 0.74 & 1.04 & 0.48 & 0.32 & 0.37 & 0.29 \\
\hline & 25.00 & 0.95 & 1.43 & 2.21 & 0.92 & 0.37 & 0.45 & 0.25 & 0.28 \\
\hline \multirow[t]{3}{*}{ Sulfur $\left(\mathrm{mg}_{\text {sulfur }} \mathrm{g}_{\text {packing }}{ }^{-1}\right)$} & 7.50 & 3.53 & 1.04 & 0.73 & 0.40 & 8.89 & 0.73 & 1.18 & 1.37 \\
\hline & 12.50 & 4.91 & 0.94 & 0.87 & 0.41 & 10.61 & 0.78 & 1.22 & 1.53 \\
\hline & 25.00 & 10.10 & 1.11 & 0.93 & 0.46 & 20.17 & 1.67 & 1.30 & 1.75 \\
\hline
\end{tabular}

Although only small fraction of $\mathrm{H}_{2} \mathrm{~S}$ entered into the upper layer, a part of elemental sulfur that accumulated in the bottom packing layer due to the incomplete bio-oxidation of $\mathrm{H}_{2} \mathrm{~S}$, could be transported into the upper layer through the recirculation of nutrient. Since these elemental sulfur could be used as the energy source for the microbial growth, biomass in the upper packing layer were maintained in relative high level.

The BTFn showed a similar vertical distribution of biomass with the range between 2.13 to $5.76 \mathrm{mg} \mathrm{g}_{\text {packing }}{ }^{-1}$. However, each packing layer in BTFn had more biomass as compared to their counterparts in BTFa. Considering that the $\mathrm{H}_{2} \mathrm{~S}$ removal performance of BTFa was superior to that of BTFn, particularly when higher inlet loading rates were supplied. It is inferred that the rate of the $\mathrm{H}_{2} \mathrm{~S}$ removal performance of the BTFn may be influenced by gas mass transfer. More biomass and elemental sulfur accumulated within the BTFn made it more difficult to transfer the substrate into the inner biofilms. This was confirmed by sulfur-oxidizing test in shaking flask (Fig. 3). Culturing planktonic cells and biofilms in the medium containing element sulfur as the sole $\mathrm{S}$ source revealed that all biofilm samples were capable of oxidizing the element sulfur. Elemental sulfur began to be rapidly oxidized after 8 hours incubation. However, no significant differences in sulfuroxidizing rates were observed between the biofilms that sampled from same packing layer in BTFa and BTFn. This finding is inconsistent with the $\mathrm{H}_{2} \mathrm{~S}$ removal of the two BTFs. As mentioned above, the drop of $\mathrm{H}_{2} \mathrm{~S}$ removal efficiency at higher inlet loading rates was more distinct in the BTFn as compared

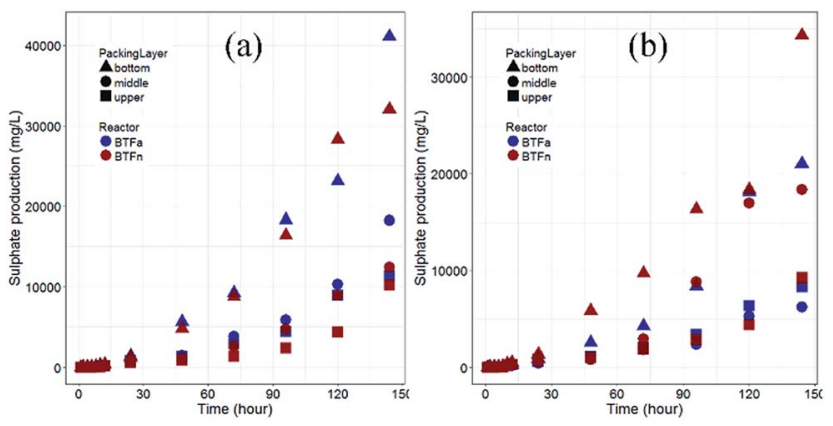

Fig. 3 In vitro sulfur-oxidizing test by inocula from each section in BTFa and BTFn (a) planktonic cells, (b) biofilm. with BTFa. It is likely that the BTFn biofilm was not oxidizing $\mathrm{H}_{2} \mathrm{~S}$ at the rate what has been found in vitro regardless more biomass accumulated in the BTFn. The overall performance of a BTF depends not only on the bio-oxidation rate but also on the mass transfer rate. The denser biofilm in the BTFn may limit the mass transfer of substrate into the deeper zone of biofilm, and therefore influenced microbial activities of the inner biofilm. It was reported that the biomass accumulation in biotrickling filters resulted in a decrease of the biofilm-specific surface area from 220 to $101 \mathrm{~m}^{2} \mathrm{~m}^{-3} \cdot{ }^{12,41}$

The sulfur-oxidizing rates of the bottom layer biofilms were significantly higher than those of the middle and upper packing layers. This partly explains why most $\mathrm{H}_{2} \mathrm{~S}$ were removed in the bottom packing layer. In addition, when the inlet loading rates increased, the amount of biomass increased in the bottom packing layer, while decreased in the middle and upper packing layers. This implies that the bottom layer biofilm was more tolerant to the shock caused by the suddenly increased inlet loading rate.

To gain better insight into the biofilm structure formed in the two BTFs, biomass also was evaluated in terms of the ratios of planktonic cells to biofilm. Table 1 showed that the mass ratios in the BTFa were in the range between 0.2 and 2.2. Comparatively, the mass ratios of planktonic cells to biofilm in the BTFn ranged from 0.05 to 0.45 , which were significantly lower than those seen in BTFa. Since the $\mathrm{pH}$ value in each packing layer of the BTFn was higher than the counterpart of BTFa (Table 2), it seems that acidic environment made it difficult to form compact biofilms on the surfaces of packing, and

Table $2 \mathrm{pH}$ values of packing from each section under different loading rate in BTFs

\begin{tabular}{llll}
\hline \multirow{2}{*}{$\begin{array}{l}\text { Sampling } \\
\text { location }\end{array}$} & \multicolumn{3}{l}{ Inlet load } \\
\cline { 2 - 4 } & $7.50 \mathrm{~g} \mathrm{~m}^{-3} \mathrm{~h}^{-1}$ & $12.50 \mathrm{~g} \mathrm{~m}^{-3} \mathrm{~h}^{-1}$ & $25.00 \mathrm{~g} \mathrm{~m}^{-3} \mathrm{~h}^{-1}$ \\
\hline BTFa-u & $3.81-4.15$ & $3.72-4.02$ & $3.81-4.12$ \\
BTFa-m & $2.81-3.12$ & $2.73-2.84$ & $2.51-2.75$ \\
BTFa-b & $1.48-1.62$ & $1.42-1.51$ & $1.40-1.44$ \\
BTFn-u & $6.80-7.33$ & $6.82-7.12$ & $6.72-7.09$ \\
BTFn-m & $4.24-5.09$ & $4.01-4.44$ & $3.51-4.07$ \\
BTFn-b & $1.98-2.49$ & $1.88-2.31$ & $1.80-2.24$
\end{tabular}


resulted that more biomass was in the form of planktonic cells. However, it is worth noting that the mass ratio of planktonic cells to biofilm in the BTFa increased from 2 to $40 \mathrm{~cm}$ of the packing layer, but $\mathrm{pH}$ also increased from 1.5 to 4.0. It is difficult to explain this contradicting result. Biofilm formation is a complex process, particularly when multiple microbes are involved in. Many environmental factors, such as $\mathrm{pH}$, inlet loading rates, microbial species, were proved to influence the architecture and physiological activity of biofilm..$^{19,42}$ In fact, the $\mathrm{pH}$ values in the bottom layer of the BTFn were also very low. So $\mathrm{pH}$ was not the only factor that influenced the biofilm development. The broader $\mathrm{pH}$ gradient in the BTFn allowed more diverse microorganisms growing in BTFn than in BTFa. Even in the same BTF, there were still differences in the amount of the sulfur source, the type of sulfur species, etc.

EPS functions as a binder during the biofilm formation, microbial cells are embedded within a self-produced matrix of EPS. ${ }^{43}$ Protein and polysaccharide were recognized as the main components of EPS. ${ }^{19}$ So the amounts of protein and polysaccharide in EPS were determined at inlet loading rates of $7.5 \mathrm{~g}$ $\mathrm{m}^{-3} \mathrm{~h}^{-1}$ and $25.0 \mathrm{~g} \mathrm{~m}^{-3} \mathrm{~h}^{-1}$. As can be seen in Table 3, polysaccharide was the dominant component in EPS for both BTFs. The amounts of polysaccharide were higher than that of protein in most cases, especially in acidic environment. The bottom packing layers of the two BTFs, where the great majority of $\mathrm{H}_{2} \mathrm{~S}$ were removed, reached the highest amount of polysaccharide as compared with the upper and middle packing layers. Furthermore, the amounts of polysaccharide in the bottom layer increased for both BTFs with increased inlet loading rates. Comparatively, protein was dominant in neutral environment. The amounts of protein in the middle and upper layer of BTFn were considerably higher than those of polysaccharide at $7.5 \mathrm{~g}$ $\mathrm{m}^{-3} \mathrm{~h}^{-1}$ of inlet loading rate. Together with these results, it is speculated that polysaccharide may play an important role in maintaining the mechanical stability of biofilm in extreme acidic conditions. This is consistent with report by Jiao et al. who observed higher carbohydrate-to-protein ratios between 3.0 and 6.0 in the acid mine drainage (AMD) solutions. ${ }^{44}$ The low protein content in the EPS of the AMD perhaps can be attributed to enzymatic digestion by extracellular proteases and protein degradation under the harsh conditions in $\mathrm{AMD} .{ }^{44} \mathrm{Li}$ et al. observed a obvious decrease of EPS and protein contents (approximate $33.3 \%$ and $70 \%$, respectively) when the $\mathrm{pH}$ of the circulating fluid was reduced from 7 to 4 , while the relative amount of polysaccharide in EPS increased. ${ }^{45}$ They considered that under strongly acidic conditions, the microorganisms increased polysaccharide production as a self-protection mechanism.

So far, only limited experimental works have been done regarding the role of $\mathrm{pH}$ in the biofilm formation, and the results in literature were very contradictory. D'Urzo et al. found that acidic $\mathrm{pH}$ (5.0) strongly enhanced the biofilm formation by a Streptococcus species, and suggested that acidic $\mathrm{pH}$ regulate the protein expression and/or promote the expression of surface-associated protein..$^{23}$ Shemesh et al. considered that the shift in $\mathrm{pH}$ is an environmental cue for the behavioural switch from motility to biofilm formation, lowering the $\mathrm{pH}$ in the medium from 4.5 to below 3.6 inhibits surface motility of Acidoterrestris and induces biofilm formation. ${ }^{24}$ The reported majority of exopolysaccharides are polyanionic due to the presence of uronic acids, organic substituents such as acetate, pyruvate, succinate, etc. Inorganic residues, such as phosphate or, rarely, sulphate, may also confer polyanionic status. ${ }^{46} \mathrm{~A}$ bridge can be formed between polysaccharide molecules through binding poly cations, to maintain the structure of biofilm. ${ }^{47}$ However, the availability of negatively charged sites of the EPS is greatly reduced in acidic environment.

\subsection{Analysis of biofilm by CLSM}

Biofilms formed at 7.5 and $25.0 \mathrm{~g} \mathrm{~m}^{-3} \mathrm{~h}^{-1}$ of inlet loading rates, respectively, were observed using CSLM. The changes of biofilm thickness were consistent with biomass (Fig. 4 and 5). Compared to BTFa, BTFn showed 53\% higher thickness of biofilm at low inlet loading rate, and $28 \%$ higher at high inlet loading rate. The thickness of biofilm decreased in BTFn with increased inlet loadings, while increased in BTFa with increased inlet loading, one exception occurred at the middle packing layer. The bottom packing layers, where exposed to the highest sulfur loading rates, developed relatively denser biofilms with an average thickness of $71 \mu \mathrm{m}$ in the BTFa, and $113 \mu \mathrm{m}$ in the BTFn. These results proved that the biofilm formation in the two BTFs was affected not only by $\mathrm{pH}$ but also by inlet loading rates.

The determination of bacterial viabilities showed that the innermost layer of all biofilms had highest bacterial viabilities. The ratio of live/total cells decreased from the substratum to the surface of biofilm in all cases. In contrast, most previous studies reported that cells close to the substratum had lower viability than those in the surface of the biofilm mainly due to the mass transfer limitation of the substrates including oxygen, nutrients. ${ }^{39,40}$ However, in the present study, most regions in the packing bed were in acidic condition despite the fact that the

Table 3 Spatial distribution of protein and polysaccharide in biofilms

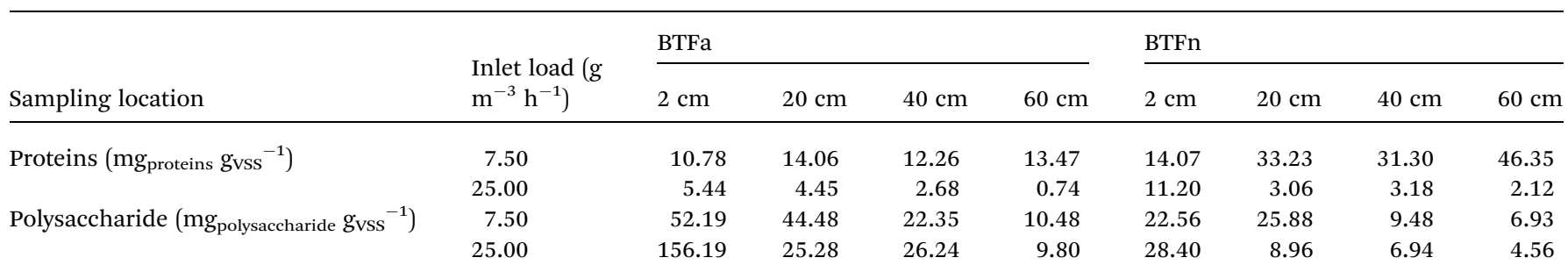




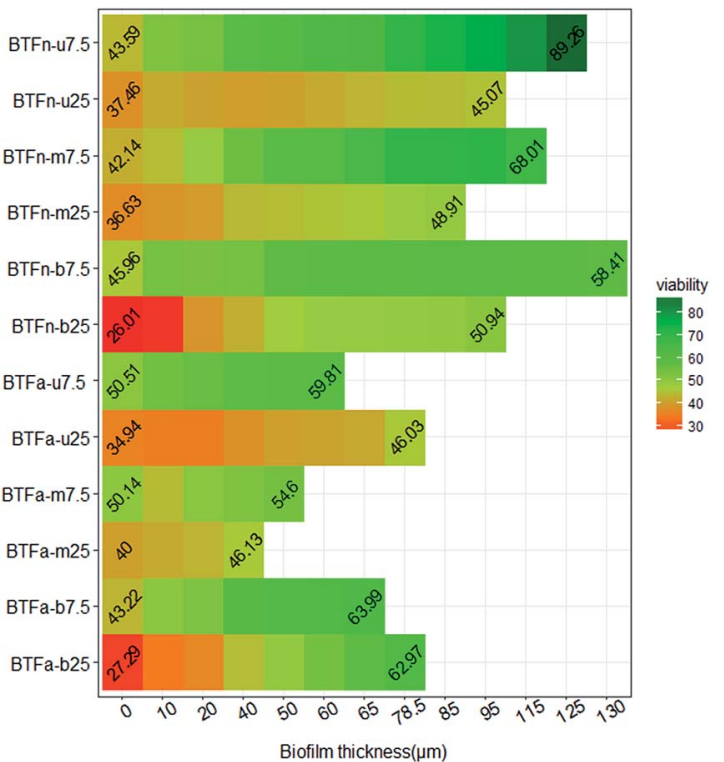

Fig. 4 Profile of biofilm thickness and cell's viability in acidic and neutral biofilms (numbers indicate the ratios of live/total cells in the outermost and the innermost zone of biofilm).

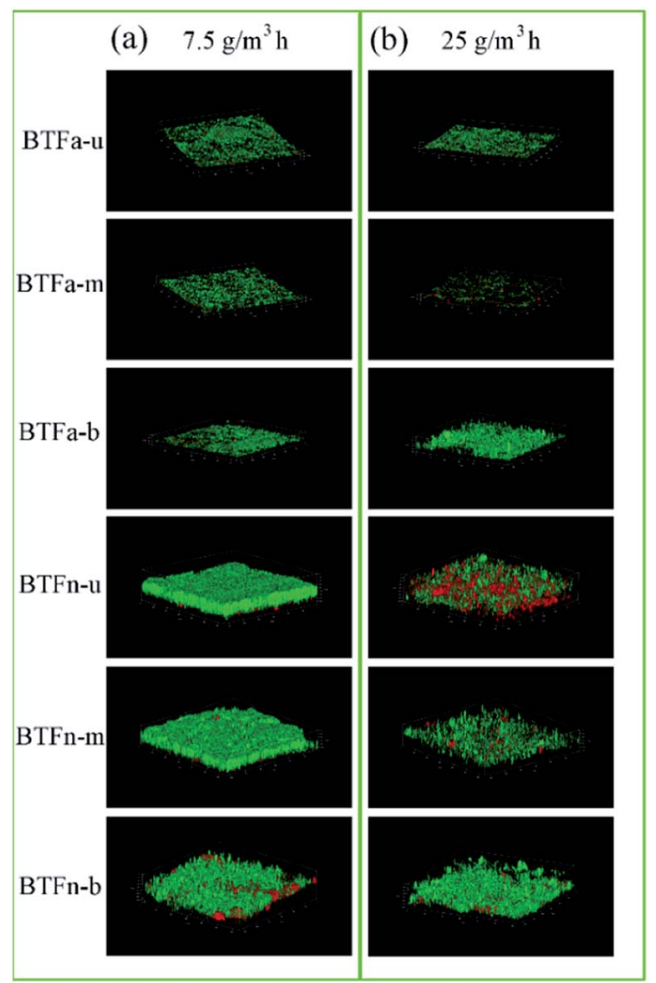

Fig. 5 BTF biofilm laser confocal images of each section under (a) $7.5 \mathrm{~g} \mathrm{~m}^{-3} \mathrm{~h}^{-1}$ and (b) $25 \mathrm{~g} \mathrm{~m}^{-3} \mathrm{~h}^{-1} \mathrm{H}_{2} \mathrm{~S}$ inlet loading rate.

$\mathrm{pH}$ value of the cycling nutrient solution was adjusted to 4.0 in the BTFa, and 7.0 in the BTFn, respectively. A mature biofilm is a well-organized community of microorganisms that adheres to surfaces and are embedded in the slimy EPS. ${ }^{48}$ The forces involves in the biofilm formation includes ionic attractive forces, electrostatic attractive forces, hydrogen bonding, etc. ${ }^{\mathbf{4 3}}$ So it can be speculated that low $\mathrm{pH}$ in the packing bed weakened these forces due to the high protonation of cation group of EPS. The stabilities of the biofilm structure therefore were reduced, and rendered the cells in the outer layer of biofilm more susceptible to acid.

Examining biofilm's feature can provide us with insight into main causes leading to the differences in the removal performance between acidic and neutral BTF. Removal performance of BTF is usually limited by either microbial degrading ability, or by mass transfer rates of pollutant. BTFn showed poorer removal performance than BTFa in removing $\mathrm{H}_{2} \mathrm{~S}$ at high inlet loading rate despite the fact that no obvious differences in biodegrading rates and cell's viability between two BTFs were observed. More biomass and thicker biofilm in BTFn made it difficult to transfer substrate from the outer biofilm to the inner biofilm, where microbial cells showed higher viabilities.

Microbial composition most likely is another key factor influencing the removal performance of BTF the structure of biofilm, cell' viability, and EPS component. Our previous study reported that the acidic BTF tended to form microbial community that composed by abundant acidophile such as Acidithiobacillus genus. These acidophile were more tolerant of the increase in the inlet loading rate and the drop of $\mathrm{pH}$. The comparative test revealed that there were some differences in the microbial viability between the two BTFs. At inlet loading rate of $7.5 \mathrm{~g} \mathrm{~m}^{-3} \mathrm{~h}^{-1}$, the average microbial viability for the upper, middle and bottom of packing layer of the BTFn were $66.8 \%, 60.4 \%$ and $56.9 \%$, respectively, higher than the corresponding values in the BTFa $(56.8 \%, 50.5 \%$ and $56.6 \%)(p<0.5)$. However, once the inlet loading rate reached to the $25.0 \mathrm{~g} \mathrm{~m}^{-3}$ $\mathrm{h}^{-1}$, both BTFs showed an obvious decrease in microbial viability of the biofilms. The decrease observed in BTFn biofilm was more distinct than that in BTFa. Average viability in the upper, middle and bottom packing layer for the BTFn sharply decrease to $41.8 \%, 43.8 \%$ and $45.4 \%$. These values for BTFa decreased to $38.9 \%, 42.8 \%$ and $45.5 \%$. The thickness of biofilm for BTFn also decreased with the increased inlet loading rate, while increased for the upper and bottom packing layer of BTFa. It can be inferred that microorganisms inside the two BTFs used different strategies to survive in unfavourable environments. Despite of the protective effect of thicker biofilm in BTFn, those microorganisms without capability of tolerating the extreme acidic conditions can be seriously damaged by high concentration of proton. This may be another cause of the drop in RE of the BTFn when the inlet loading rate increased to the higher levels. Comparatively, microorganisms developed inside BTFa produced more polysaccharide to maintain the stability of biofilm's structure and cell's viability. However, the formation of multispecies biofilm is more complex compared to the single strain. As reported by Bellenberg et al. the biofilm formation on the pyrite involved a certain interaction between species, the presence of iron-oxidizers enhanced the attachment of sulfuroxidizers on the pyrite by producing the reduced inorganic sulfur compounds for the latter. ${ }^{49}$ Thus, many studies should be 
performed to further elucidate the mechanism of multispecies biofilm formation.

\section{Conclusion}

In this study, the performances of two biotricking filters in removing $\mathrm{H}_{2} \mathrm{~S}$ under acidic and natural conditions were evaluated. The biofilm structure and stability was mainly analyzed based on the data of biomass, EPS component, cell's viability and thickness of biofilm. The study revealed that both $\mathrm{pH}$ and inlet loading rates affected the biofilm structure and stability. Biofilm formed in the neutral BTF was less tolerant with shock loads than that in the acidic BTF despite the fact that the neutral BTF had more biomass than the acidic BTF. It is more likely that the performance of BTF depended more on the type of microorganisms than on the biomass. The increase of the ratio of planktonic cells to biofilm in acidic BTF illustrated that pH seriously affected the stability of biofilm. The polysaccharide was found in high levels in acidic biofilms. It can be speculated that microbial cells alleviated acidic stress mainly by producing more polysaccharide since it can provide more cation-binding sites.

\section{Acknowledgements}

This work was financially supported by Natural Science Foundation of China (31270169), Science and Technology Project of Guangzhou, China (201504010014, 201704020204), and Science and Technology Project of Guangdong Province, China (2014A020216022, 2016B070701017).

\section{References}

1 B. S. Giri and R. A. Pandey, Bioresour. Technol., 2013, 142, 420-427.

2 Y. Cheng, H. He, C. Yang, G. Zeng, X. Li, H. Chen and G. Yu, Biotechnol. Adv., 2016, 34, 1091-1102.

3 R. Lebrero, E. Rodríguez, M. Martin, P. A. García-Encina and R. Muñoz, Water Res., 2010, 44, 3905-3914.

4 S. Mudliar, B. Giri, K. Padoley, D. Satpute, R. Dixit, P. Bhatt, R. Pandey, A. Juwarkar and A. Vaidya, J. Environ. Manage., 2010, 91, 1039-1054.

5 A. Gonzàlez-Sànchez, S. Revah and M. A. Deshusses, Environ. Sci. Technol., 2008, 42, 7398-7404.

6 E. Y. Lee, N. Y. Lee, K. S. Cho and H. W. Ryu, J. Biosci. Bioeng., 2006, 101, 309-314.

7 G. Rodriguez, A. D. Dorado, M. Fortuny, D. Gabriel and X. Gamisans, Process Saf. Environ. Prot., 2014, 92, 261-268.

8 J. Li, G. Ye, D. Sun, G. Sun, X. Zeng, J. Xu and S. Liang, Appl. Microbiol. Biotechnol., 2012, 95, 1633-1641.

9 G. Aroca, H. Urrutia, D. Núñez, P. Oyarzún, A. Arancibia and K. Guerrero, Electron. J. Biotechnol., 2007, 10, 514-520.

10 R. Lebrero, A. C. Gondim, R. Pérez, P. A. García-Encina and R. Muñoz, Water Res., 2014, 49, 339-350.

11 X. Tu, J. Li, R. Feng, G. Sun and J. Guo, PLoS One, 2016, 11, e0155593, DOI: 10.1371/journal.pone.0155593.
12 B. S. Giri, K. H. Kim, R. A. Pandey, J. Cho, H. Song and Y. S. Kim, Process Biochem., 2014, 49, 1543-1554.

13 R. M. Donlan, Emerg. Infect. Dis., 2002, 8, 881-890.

14 R. M. Donlan, Curr. Top. Microbiol. Immunol., 2008, 322, 133161.

15 A. Courtois, Y. Andrès and D. Éric, J. Chem. Technol. Biotechnol., 2014, 90, 50-56.

16 A. M. Montebello, M. Mora, L. R. López, T. Bezerra, X. Gamisans, L. Lafuente, M. Baeza and D. Gabriel, J. Hazard. Mater., 2014, 280, 200-208.

17 M. B. Jaber, B. Anet, A. Amrane, C. Couriol, L. Lendormi, P. L. Cloirec, C. Cogny and R. Fillières, Chem. Eng. J., 2014, 258, 420-426.

18 S. Veerachamy, T. Yarlagadda, G. Manivasagam and P. K. Yarlagadda, Proc. Inst. Mech. Eng., Part H, 2014, 228, 1083-1099.

19 T. T. More, J. S. S. Yadav, S. Yan, R. D. Tyagi and R. Y. Surampalli, J. Environ. Manage., 2014, 144, 1-25.

20 M. A. Deshusses, G. Hamer and I. J. Dunn, Environ. Sci. Technol., 1995, 29, 1048-1058.

21 A. Pagedar and J. Singh, J. Food Sci. Technol., 2015, 52, 53175322.

22 R. Xing, S. P. Lyngstadaas, J. E. Ellingsen, S. Taxtlamolle and H. J. Haugen, Clin. Oral Implants Res., 2015, 26, 649-656.

23 N. D'Urzo, M. Martinelli, A. Pezzicoli, V. D. Cesare, V. Pinto, I. Margarit, J. L. Telford and D. Maione, Appl. Environ. Microbiol., 2014, 80, 2176-2185.

24 M. Shemesh, R. Pasvolsky and V. Zakin, J. Food Prot., 2014, 77, 1418-1423.

25 H. Hall-Stoodley and P. Stoodley, Curr. Opin. Biotechnol., 2002, 13, 228-233.

26 S. K. Sudhir and T. S. Rao, Colloids Surf., B, 2013, 103, 448454.

27 W. Dec, M. Mosiałek, R. P. Socha, M. Jaworska-Kik, W. Simkad and J. Michalska, Electrochim. Acta, 2016, 212, 225-236.

28 A. Mannucci, G. Munz, G. Mori and C. Lubello, Chemosphere, 2012, 88, 712-717.

29 K. Harneit, A. Göksel, D. Kock, J.-H. Klock, T. Gehrke and W. Sand, Hydrometallurgy, 2006, 83, 245-254.

30 M. Ramírez, M. Fernández, C. Granada, S. L. Borgne, J. M. Gómez and D. Cantero, Bioresour. Technol., 2011, 102, 4047-4053.

31 L. Zhu, M. L. Lv, X. Dai, Y. W. Yu, H. Y. Qi and X. Y. Xu, Bioresour. Technol., 2012, 107, 46-54.

32 Y. Liu and J. H. Tay, Water Res., 2012, 36, 1653-1665.

33 D. Kim and G. A. Sorial, Chemosphere, 2007, 66, 1758-1764.

34 R. A. Bobadilla Fazzini, M. P. Cortés, L. Padilla, D. Maturana, M. Budinich, A. Maass and P. Parada, Biotechnol. Bioeng., 2013, 110, 2242-2251.

35 Z. Zhu and X. Qiao, Chin. J. Chromatogr., 1997, 15, 81-82.

36 Y. Zhao, X. Liang, N. An, Z. Wei and M. Wang, Acta Mineral. Sin., 2006, 26, 29-32.

37 Y. Yang, Y. Xiang, C. Xia, W. M. Wu, G. Sun and M. Xu, Bioresour. Technol., 2014, 164, 270-275.

38 B. S. Giri, M. Goswami, R. A. Pandey and K. H. Kim, Biochem. Eng. J., 2015, 102, 108-114. 
39 M. E. López, E. R. R. Rene, L. Malhautier, J. Rocher, S. Bayle, M. C. Veiga and C. Kennes, Bioresour. Technol., 2013, 138, 245-252.

40 M. Ramirez, J. M. Gómez, D. Cantero, J. Páca, M. Halecký, E. I. Kozliak and M. Sobotka, Folia Microbiol., 2009, 54, 409-414.

41 B. Mielich-Süss and D. Lopez, Environ. Microbiol., 2015, 17, 555-565.

42 C. Yang, H. Chen, G. Zeng, G. Yu and S. Luo, Biotechnol. Adv., 2010, 28, 531-540.

43 H. C. Flemming and J. Wingender, Nat. Rev. Microbiol., 2010, 8, 623-633.
44 Y. Jiao, G. D. Cody, A. K. Harding, P. Wilmes, M. Schrenk, K. E. Wheeler, J. F. Banfield and M. P. Thelen, Appl. Environ. Microbiol., 2010, 76, 2916-2922.

45 H. Li, S. Huang, S. Zhou, P. Chen and Y. Zhang, Appl. Microbiol. Biotechnol., 2016, 100, 1-11.

46 D. Martin, F. Stanley and R. Eugene, The Prokaryotes, Springer Verlag, Berlin, Heidelberg, 2006.

47 A. Aguilera, V. Souza-Egipsy, P. San Martín-Uriz and R. Amils, Appl. Microbiol. Biotechnol., 2008, 78, 1079-1088.

48 S. Molin and T. Tolker-Nielsen, Curr. Opin. Biotechnol., 2003, 14, 255-261.

49 S. Bellenberg, M. Díaz, N. Noël, W. Sand, A. Poetsch, N. Guiliani and M. Vera, Res. Microbiol., 2014, 165, 773-781. 